OPEN ACCESS

Citation: Diego Garzia, Gianluca Passarelli (2021) Italy in times of protest and negative voting: An introduction. Quaderni dell'Osservatorio elettorale - Italian Journal of Electoral Studies 84(2): 3-7. doi: 10.36253/qoe-12279

Received: October 30, 2021

Accepted: November 8, 2021

Published: November 10, 2021

Copyright: @ 2021 Diego Garzia, Gianluca Passarelli. This is an open access, peer-reviewed article published by Firenze University Press (http://www. fupress.com/qoe) and distributed under the terms of the Creative Commons Attribution License, which permits unrestricted use, distribution, and reproduction in any medium, provided the original author and source are credited.

Data Availability Statement: All relevant data are within the paper and its Supporting Information files.

Competing Interests: The Author(s) declare(s) no conflict of interest.

Orcid

DG: 0000-0001-8767-4099

GP: 0000-0002-3300-0790

\section{Italy in times of protest and negative voting: An introduction}

\author{
Diego Garzia ${ }^{1}$, Gianluca Passarelli ${ }^{2, *}$ \\ ${ }^{1}$ University of Lausanne, Switzerland \\ ${ }^{2}$ University Sapienza Rome, Italy \\ *Corresponding author. Email: gianluca.passarelli@uniroma1.it
}

\begin{abstract}
The classic heuristics of voting behaviour have been eroded overtime especially in well-established democracies. Ideology, party identification, and social class have been gradually replaced by short-period factors. In particular, the personalization has represented an innovative variable that significantly contributes to explain voting behaviour. Cross-pressures between party identification, candidate assessments and issue preferences paved the way to the diffusion of protest voting, both against the élite and the system. In this respect, Italy represents a very interesting case from both a theoretical and an empirical point view considering the presence of protest parties and the important diffusion of anti-system movements which surfed the protest to consolidate their positions. The editors conceived this special issue aiming at analysing and measuring the impact of protest/negative voting in Italy between 2016 and 2020, a period in which protest parties and voters' discontent have significantly increased. Data presented by the different papers confirm, albeit under different perspectives, the relevance of this peculiar form of political behaviour.
\end{abstract}

Keywords: Italian referenda, negative voting, personalization of politics, protest voting.

\section{THE DECLINE OF STRUCTURAL DETERMINANTS OF ELECTORS' DECISION}

Elections are decisive and crucial for democracy and the political system. However, the drivers of electoral behaviour have changed over time. The relationship between parties and voters/citizens has weakened, and in some contexts even dramatically. Due to the intertwined processes of social modernization, increasing de-ideologization, the weakening of parties' organizations, and the resulting partisan dealignment trend, individual short-terms factors have progressively replaced structural determinants of voters' decision. Voters nowadays are increasingly more likely to cast their ballots based on the assessment of candidates and party leaders, the evaluation of the economy, and the proposals put forward in the political campaign.

This move towards a disintermediated electorate has apparently resulted (also) in rising levels of negativity against incumbents, mainstream parties, and/or representative democracy altogether. Comparative analyses have 
uncovered a long-term development of increasing distrust in political parties and leaders across the Western world (van der Meer, 2017). Moreover, a progressive weakening in party-voter linkages was amplified by, e.g., the decline of traditional ideologies, the decline of party membership, as well as the increase in electoral abstention (Dalton and Wattenberg, 2000; Dalton, 1996). Voters' loyalty to parties has dramatically decreased and most of the political systems faced a process of partisan dealignment, where short time factors have replaced the ideologically driven mass parties (Garzia et al., 2020). A diffused discontent towards parties and politics has grown, and also the democratic system has been challenged by a wave of protest and mistrust.

Among the consequences of this riding tide of political distrust, it has been observed a tendency among voters to increasingly dislike parties and candidates they do not support--while becoming more ambivalent toward parties they support. Available research shows that voters' evaluation of their own parties and candidates is stable, yet voters have come to dislike their opponents more over time (Abramowitz and Webster, 2016; Garzia and Ferreira da Silva, 2021a).

Against a background of increasing animosity towards political opponents, it comes as no surprise that an increasing amount of published electoral research has moved its attention away from the determinants of 'voting for' a party or candidate, to focus explicitly on the underlying reasons behind citizens' choice to cast a 'vote against'. Several labels have been used by previous scholarship to describe largely overlapping phenomena such as protest voting (Alvarez et al., 2018) or anti-incumbent voting (Thorson and Stambough, 1995). Indeed, early rational choice scholarship conceived negative voting as a special case of retrospective voting in elections involving incumbents (Kernell, 1977). The wear and tear of holding office increases the likelihood of discontent with presidential performance among voters, leading in turn to a higher rate of votes against the incumbent.

The intuitive value of this empirically testable proposition is however counterbalanced by its inability to account for negative votes cast against the challenger, nor about the very existence of negative voting in elections involving no incumbent. As aptly summarized by Fiorina and Schepsle $(1989,424)$ negative voting appeared as "an observed regularity with an as-yet uncertain explanation".

Drawing from cognitive dissonance theory, a strand of psychological literature conceived negative voting as a rationalization mechanism among voters facing conflicting preferences between party identification, ideology and candidate assessments (Gant and Sigelman 1985;
Sigelman and Gant 1989). A more recent strand of scholarship has tackled the issue of negative voting through the lens of negative partisanship. The idea that hostility toward the out-group can develop independently from - and drive support for - the in-group is indeed at the core of the social identity perspective on negative voting (Medeiros and Noël, 2014; Abramowitz and Webster, 2016; Bankert, 2020). In parallel, research on the personalization of politics (Poguntke and Webb 2005; Passarelli 2015; Elgie and Passarelli 2019; Garzia et al., 2020) finds that negative attitudes toward the political out-group concern not only political parties but can also spill over to individual candidates (Barisione, 2017). Accordingly, evaluations of (out-party) candidates have been shown to also act as determinants of the vote, acting alongside positive (in-party) candidate evaluations (Garzia and Ferreira da Silva, 2021a).

Taking stock of the existing empirical literature, we follow Garzia and Ferreira da Silva (2021b, 2) and summarize the tendency towards negative voting as driven by three micro-behavioural components, "namely: (1) an instrumental-rational component characterized by retrospective performance evaluations and rationalization mechanisms; (2) an ideological component grounded on long-lasting political identities; and (3) an affective component, motivated by (negative) attitudes towards parties and candidates".

\section{PROTEST, NEGATIVE VOTING, AND DISTRUST: THE ITALIAN CASE}

On the one hand, voting has become more and more oriented by factors related to the performance of the governments and, therefore, of the political activities of the parties supporting the executives in the parliament. On the other hand, voters seem to be keener to vote against the incumbents based on a retrospective evaluation. This widespread political behaviour has been labelled as 'protest voting', that is, a vote in favour of parties which are not expression of the 'system', and in which the electoral decision is barely focused on political attitudes but rather against the élite (Van Der Brug et al., 2000). In order to make the analysis clear it is important to distinguish between two kinds of protest.

The elite discontent concerns the incumbent government and the parties supporting it, as well as the executive performance. The second - system discontent - refers to democratic elements of politics such as parties, politicians, institutions, and the functioning of democracy. On this line of research, Bergh found that protest voting mainly reflected a reaction against politi- 
cal elites, rather than against the political system itself (Bergh, 2004: 386). Objects of protest can be the regime, the political community, the system, the policies, or the political parties. It is possible then to indicate two main arenas on which 'protest' can be measured: (1) a vote against the establishment and (2) a vote unconnected to policy preferences. Therefore, in order to express their discontent, voters think to 'send a message' to the élite by supporting protest parties, which are not merely those in the opposition but rather the political forces who claim to represent the protest per se. their agenda is often based on the rejection of the existing system, as well as on the harsh criticism towards the élite (political and economic) as well as against the incumbent.

The Italian case fits well the framework of analysis of the negative and protest voting for both theoretical and empirical reasons. For one thing, Italy does represent a relevant case of success of populist parties, which collected many protest votes also thank to electoral campaigned based on the emphasis on the reject of all the existent and established ruling class (Bergman and Passarelli 2016; Bergman et al. 2021). Protest parties and anti-system parties are well present in the history and in the recent past of the country. The electoral performance of these parties tests the importance of Italy in dealing with the analysis of the protest voting, as well as their relevance in disentangling conceptual aspects of the negative vote in general. The collapse of the party system in the early Nineties was at the same time started by protest parties and it paved the way to the emergence of new" protest parties. Voters more and more supported political forces who claimed to dismiss the old élite and to fight again corruption and the inefficacy of the incumbents. In 1994 a new populist party, Forza Italia, reached the first place in the general elections, together with the exploit of the sub-national xenophobic Northern League. The apex of the populist forces was in 2013 (Bellucci 2014; Passarelli and Tuorto 2014) when the protest voting gathered the highest percentages also thank to the unexpected performance of the Five Star Movement who mostly claimed the protest both against the élite and the incumbents. Finally, in 2018 the two main populist parties obtained more than 50 per cent of the consensus, emphasising their protest trait and then making a governmental alliance. In fact, the Five Star Movement and the Lega Nord surfed the protest (Passarelli and Tuorto 2018).

The empirical analysis reported in this special issue clearly support the relevance of the increasing presence of the negative voting as a factor explaining voting behaviour in the Italian context. Indeed, Italy seems to be a sort of natural laboratory where the impact of psychological determinants, context elements, and person- alised campaign have deployed their effects of the voters' decision-making process. These attitudes have been detected in both national election and in the constitutional referenda hold in the last quart of century.

\section{CONTENT OF THIS SPECIAL ISSUE}

The first paper of the special issue by Dario Tuorto moves from the aforementioned background of increasing dealignment and electoral volatility to investigate the emerging trend of issue incongruency. The presence of a new ideological conflict - the so-called liberalauthoritarian cleavage - emphasized the redefinition of the link between issue and voting preferences. Tuorto indicates that in the Italian case, even if distinct political spaces still exist, voter's preferences are not always internally coherent and do not automatically reflect on the expected (propensity to) vote for a given party. An important finding in his analysis is that issue incongruency is more pronounced among voters oriented towards the centre-right parties, whereas relative openness on the issue 'right for new families' combines with a position of absolute closeness on the issue 'immigration'. The author also investigates the contribute of the young people in such dynamic, showing that they are not the first and the only responsible for the emergence of a less structured political space.

The paper by Matthew Bergman and Gianluca Passarelli zooms in on the very notion of 'protest voting' by looking at a relatively underexplored context: the Italian referenda of 2016 and 2020. While existing scholarship has repeatedly pointed to the notion that referenda provide voters with the chance to express their own policy preferences, Bergman and Passarelli argue that voters' motivations could be (more) strongly shaped with satisfaction/dissatisfaction with incumbent governments' parties and performance. By means of multi-variate regression analyses, they examine the relationship between economic discontent, satisfaction with the governing coalition and leaders, belief in the content of the reforms, and vote choice in the 2016 and 2020 referenda. Their results show that referendum-specific factors had the strongest predictive power followed by those related to government approval - thus pointing to the idea that referenda remain largely (though not exclusively) about the policy proposals on the table and regardless of their proponents.

In the third article of this special issue, Fabio Bordignon and Luigi Ceccarini tackle the issue of institutionalization on behalf of formerly anti-establishment parties, who eventually gain strength and enter institutions. To do so, they rely on three crucial cases of par- 
ties benefitting from protest voting as key driver of their electoral fortunes, i.e., in the authors' definition, "the three main protagonists of the 2016-2020 Italian populist wave: the Movimento 5 Stelle, the Lega Nord, and Fratelli d'Italia". They rely on ITANES (Italian National Election Study) panel data and measure the evolution of populist attitudes and protest drivers, as well as their connection with electoral flows and parties' strategic choices. Among the key findings, they highlight the decrease in populist attitudes among those M5S voters who remained loyal to their party throughout the window of observation. At the same time, their insightful analysis of electoral flows shows that voters remaining high on the populism score found a secure harbour further to the right, most notably Lega and FDI. If referenda are still largely about issues, electoral consensus remains largely about political representation. Some voters do change their positions as a result of their party's repositioning. However, many (if not the majority of) voters do change their party preference in line with those representing their opinions best.

The following article by Mauro Bortolotti, Claudia Leone and Patrizia Catellani takes it from here to expand our current knowledge on the determinants of populist support. While a large body of existing research has investigated the political and economic factors at the core of populist parties' success, they argue that much less empirical research has been devoted to the individual psychological factors associated with populist attitudes. The authors rely again on the ITANES 2016-2020 panel and the 6-item populism battery also employed by Bordignon and Ceccarini, and find most notably that populist attitudes are "strongly associated with psychosocial factors, such as nationalism, political efficacy, and conspiracist beliefs". Their analysis also adds on Bergman and Passarelli's by showing that populist attitudes have explanatory power in their own when it comes to vote choice at both the 2016 and 2020 referenda, even after controlling for voters' evaluation of the reform and political/attitudinal variables.

The final article of this collection, authored by Giuliano Bobba, Moreno Mancosu, Franca Roncarolo, Antonella Seddone and Federico Vegetti, explores the issue of electoral losers' bias. Voters are known to update their past perceptions and future expectations depending on whether their own party wins or loses the elections. In their paper, they investigate whether such a winner-loser effect conditions people's concerns about the Covid-19 pandemic. Beyond the conjuncture of the health problem affecting citizens' life, the paper indicates that voters losing elections do not change their concerns and fer of the future. Using pre-/post-elec- tion panel data, authors show that losing an election (a regional one in the study) can affect citizens' outlook on future events so with potential consequences on affecting their behavior beyond the tradition schema of political belonging and proximity.

\section{WHAT WE HAVE LEARNED FROM THE ITALIAN CASE 2016-2020}

The relevance of this special issue steams from two complementary aspects: theoretical and empirical. The cases investigated and their different approaches are mostly consistent with the negative voting framework. General elections and referenda in Italy show common patterns of voters' behavior mainly explained by a vote 'against'. The retrospective evaluation, typically necessary for casting a negative vote, has been at the core of the voters' behavior in Italy in the 2018 general elections and in two referenda in 2016 and 2020. The personalization of the vote, and, therefore, the possibility to cast a vote 'against' has been detected also in sub-national contexts. The discrepancy between voters' characteristics and their attitudes on issues and their vote for parties far from their values represented an increasing trend also in youth generation and confirms the weakening of long-term factors structuring the vote. All in all, the Italian case under investigation between 2016 and 2020 represents a very important case to enhance the quality and quantity of information about the negative voting. Data presented in this special issue are not only relevant for the Italian case per se but rather can be used to carry comparative analyses.

\section{REFERENCES}

Abramowitz, A. I., \& Webster, S. (2016). The rise of negative partisanship and the nationalization of US elections in the 21st century. Electoral Studies, 41, 12-22.

Alvarez, R. M., Kiewiet, D. R., \& Núñez, L. (2018). A taxonomy of protest voting. Annual Review of Political Science, 21, 135-154.

Bankert, A. (2020). Negative and positive partisanship in the 2016 US presidential elections. Political Behavior, 43, 1467-1485.

Barisione, M. (2017). The partisan gap in leader support and attitude polarization in a campaign environment: the cases of Germany and Italy. International Journal of Public Opinion Research, 29(4), 604-630.

Bellucci, P (2014) The political consequences of blame attribution for the economic crisis in the 2013 Italian 
national election. Journal of Elections, Public Opinion and Parties, 24(2), 243-263.

Bellucci, P, Lobo, MC, Lewis-Beck, MS (2012) Economic crisis and elections: The European periphery. Electoral Studies, 31(3), 469-471.

Bergh, J (2004) Protest voting in Austria, Denmark and Norway. Scandinavian Political Studies, 27(4), 367-389.

Bergman, M. and G. Passarelli (2021) Conflicting Messages of Protest: The Italian 2016 Referendum. Politics, doi: 10.1177/0263395720974975, 1-20.

Bergman, M., G. Passarelli and F. Serricchio (2020) Decades of Party Distrust: Persistence through Reform in Italy. QOE-IJES Italian Journal of Electoral Studies, 83(2), 15-25.

Van Der Brug, W, Fennema, M, Tillie, J (2000) Antiimmigrant parties in Europe: Ideological or protest vote? European Journal of Political Research, 37(1), $77-102$.

Elgie, R. and G. Passarelli (2019) Presidentialisation: One term, Two Uses - Between Deductive Exercise and Grand Historical Narrative. Political Studies Review, 17(2), 115-123.

Fiorina, M. P., \& Shepsle, K. A. (1989). Is negative voting an artifact? American Journal of Political Science, 33(2), 423-439.

Gant, M. M., \& Sigelman, L. (1985). Anti-candidate voting in presidential elections. Polity, 18(2), 329-339.

Garzia, D., Ferreira da Silva, F., \& De Angelis, A. (2020). Partisan dealignment and the personalisation of politics in West European parliamentary democracies 1961-2018. West European Politics, 45(2), 311-334.

Garzia, D., \& Ferreira da Silva, F. (2021a). Negative personalization and voting behavior in 14 parliamentary democracies 1961-2018. Electoral Studies, 71, 102300.

Garzia, D., \& Ferreira da Silva, F. (2021b). Negativity and Political Behavior: A Theoretical Framework for the Analysis of Negative Voting in Contemporary Democracies. Political Studies Review, doi: 10.1177/14789299211000187.

Kernell, S. (1977). Presidential popularity and negative voting: An alternative explanation of the midterm congressional decline of the president's party. American Political Science Review, 71(1), 44-66.

Medeiros, M., \& Noël, A. (2014). The forgotten side of partisanship: Negative party identification in four Anglo-American democracies. Comparative Political Studies, 47(7), 1022-1046.

Passarelli, G. (2015) (ed.) The Presidentialization of Political Parties. London: Palgrave.

Passarelli, G. and D. Tuorto (2014) Not with my vote. Turnout and the Economic Crisis in Italy. Contemporary Italian Politics, 6(2), 147-158.
Passarelli, G. and D. Tuorto (2018) The Five Star Movement: purely a matter of protest? The rise of a new party between political discontent and reasoned voting. Party Politics, 24(2), 129-140.

van der Meer, T. W. (2017). Political trust and the "crisis of democracy". Oxford Research Encyclopedia of Politics.

Sigelman, L., \& Gant, M. M. (1989). Anticandidate voting in the 1984 presidential election. Political Behavior, 11(1), 81-92.

Thorson, G. R., \& Stambough, S. J. (1995). Anti-incumbency and the 1992 elections: The changing face of presidential coattails. The Journal of Politics, 57(1), 210-220. 